\title{
Assessment of groundwater potentiality using geospatial techniques in Purba Bardhaman district, West Bengal
}

\author{
Subodh Chandra Pal ${ }^{1}$ (1) $\cdot$ Chiranjit Ghosh ${ }^{1} \cdot$ Indrajit Chowdhuri $^{1}$
}

Received: 21 January 2020 / Accepted: 3 September 2020 / Published online: 19 September 2020

(c) The Author(s) 2020

\begin{abstract}
The word water is life, so life on this planet cannot be possible without water. Water is an essential natural resource that is a surface and groundwater device for human society. The purpose of this research is to assess the groundwater potentiality of the Purba Bardhaman district. All data (primary and secondary) are collected from different sources and analyzed in geographic information system (GIS) software to prepare thematic maps. Different geo-environmental factors like as land use and land cover, soil, lithology, rainfall and distance from the river, etc., can impact on groundwater availability directly or indirectly in Purba Bardhaman area. To identify groundwater potential zones, all these factors are composed into GIS software using multi-criteria decision analysis (MCDA) method. The groundwater potential map has been divided into five classes based on their magnitude as very high, high, medium, low and very low groundwater potential zones. It shows that the areas of very low, low, medium, high and very high groundwater potential zones are $21.54 \%, 35.80 \%, 26.47 \%, 10.13 \%$, $6.06 \%$, respectively, of the total area. Finally, validation is carried out using groundwater depth data collected from 44 drilled tube wells which are located in a scattered manner for whole Purba Bardhaman district which indicates a higher similarity with an area under curve value of $86.8 \%$.
\end{abstract}

Keywords Groundwater · Purba Bardhaman · Multi-criteria decision analysis · GIS

\section{Introduction}

Groundwater is a dynamic resource that plays a vital role in nurturing an ecological balance (Das 2017). The largest freshwater resource in the world is groundwater. Today, the maximum rural population and the total urban population depend on groundwater for their basic needs. Proper management strategies cannot be developed in the context of the groundwater decay scenario due to lack of knowledge in this area. Maximum groundwater is needed for agriculture, drinking water and industry. The absence of groundwater is a common phenomenon in India due to the use of groundwater without proper scientific planning (Rodell et al.

Subodh Chandra Pal

geo.subodh@gmail.com

Chiranjit Ghosh

chiranjitghosh.64@gmail.com

Indrajit Chowdhuri

indrajitchowdhuri@gmail.com

1 Department of Geography, The University of Burdwan, Bardhaman, West Bengal, India
2009). The most valuable resource is groundwater which is unevenly distributed. Distribution of groundwater is controlled according to many criteria, i.e., lithology, geological structure, lineaments, soil, slope, drainage density, distance from the river, vegetation cover, surface water scenario, land use and land cover, rainfall, climatic condition and interrelationship between these factors (Sar et al. 2015; Jothibasu and Anbazhagan2016; Dasho et al.2017).

Six main criteria were used to analyze the groundwater potential of Purba Bardhaman, i.e., soil, land use and land cover, lithology, surface water scenario, water distance and rainfall. In this plain region, they are the most effective. Remote sensing (RS) and GIS techniques (Krishnamurthy et al. 1996; Pothiraj and Rajagopalan 2013; Sar et al. 2015; Anbazhagan and Jothibasu 2016; Jothibasu and Anbazhagan 2017; Choudhari et al. 2018; Das and Pal 2019a, b) are very much useful to delineate the groundwater potential zone. Many researchers in India and aboard have been successfully using this technique to identify groundwater potential zone. Thematic layers have been made through Arc GIS software. Recently, the application of multi-criteria decision making (MCDM) technique in GIS framework plays an important 
role in scientific investigation in groundwater resource management (Chen et al. 2011). The other areas where MCMD technique and GIS both play a vital role, are natural hazard (Ozturk and Batuk 2011), agriculture (Cisneros et al. 2011) and forestry (Zeng et al. 2007). Analytic hierarchy process (AHP) by Saaty of MCMD is playing a vital role to solve socioeconomic decision-making problems (Jhariya et al. 2016; Pal et al. 2019; Das and Pal 2020). In the AHP model, priority is given not only to the single element, but also to the cluster of elements that are often needed (Saaty 1999). In this paper, the AHP model was successfully used to assign relative importance to parameters that elucidate potential groundwater areas (Machiwal et al. 2015; Jhariya et al. 2016; Dasho et al. 2017; Das et al. 2017; Chakrabortty et al. 2018; Das et al. 2019). The main aim of this work is to identify the groundwater potential area of Purba Bardhaman district through the application AHP method and GIS technique. This study may be helpful in future planning for sustainable groundwater management which may help the people from water crisis.

\section{Study area}

The Purba Bardhaman district consisted of an alluvial plain. The study area is enclosed between $22^{\circ} 15^{\prime} 08^{\prime \prime} \mathrm{N}$ to $23^{\circ} 15^{\prime} 17^{\prime \prime} \mathrm{N}$ latitudes and $87^{\circ} 13^{\prime} 17 \mathrm{E}$ to $88^{\circ} 7^{\prime} 22^{\prime \prime}$ E longitudes (Fig. 1). In this district, the three major rivers are Ajay, Bhagirathi and Damodar, which are situated on the north, east and south side of the district. The undulating lateritic topography is found in the Ausgram region, which is part of the Paschim Bardhaman district. The study area is part of the tropical region. According to the 2011 census, the total population of the district was 48,35,532. Agriculture with a limited number of agricultural industries is a main occupation in this region. In this analysis, there are 11 community blocks, i.e., Ketugram-I, Ketugram-II, Bhatar, Raina-I, Raina-II, Kalna-II, Mongalkote, Katwa-II, Katwa-I, Memari-II, Monteswar were identified as semicritical blocks (CGWB 2013) out of 23 community blocks, and there is a long-term trend in water level fluctuations (CGWB 2016). The central part of this study area received sufficient amount of rainfall which is categorized as high for this study region, i.e., above $1400 \mathrm{~mm}$. The maximum part of this study region encompases with the distribution of 1200 to $1400 \mathrm{~mm}$ rainfall, whereas rest of the region has received below $1200 \mathrm{~mm}$ rainfall per year.

\section{Database and methodology}

Various types of data are presented here in the tabulated form which has been used for preparing the groundwater potential zone in Purba Bardhaman district. The analyses have been started after the collection of all the required datasets. Numerous types of data (Table 1) and software like ArcGIS 10.3 and ERDAS IMAGINE 2014 have been used in this work. In this work, six criteria, i.e., lithology, soil texture, rainfall, distance from river, surface water body and land use land cover, have been taken into consideration to prepare groundwater potential zone. All the maps have been transformed into Universal Transverse Mercator (UTM) projection northern zone 45 datum WGS 1984 in ArcGIS software. Four thematic layers such as lithology, rainfall, distance from the river and soil texture have been digitized and rectified from various sources which are already mentioned in Table 1 . We used the ERDAS 9.0 software for satellite image processing. The maximum likelihood classification method of supervised classification was applied for land use land cover map using the same Landsat 8 OLI satellite imagery of 2019 and software. The surface water body has been extracted using the normalized difference water index (NDWI) method from the same satellite image in ArcGIS 10.3 software. There are various water extraction methods, and one of them is the NDWI method which is used in this paper. Equation of NDWI is as follows:

NDWI $=($ Green - NIR $) /($ Green + NIR $)$

After preparation of all thematic layers, the AHP method has been applied. Regarding this, the spatial distributions of all geo-environmental variables are from different data sources. AHP is a semiquantitative approach. In the AHP model, score is representing the importance of every individual factor (Saaty 1977, 2000). The preference values are applied for each factor following the importance scale of AHP for the calculation of relative importance in association with the goal (Saaty 1977; Saaty and Vargas 2001).

\section{Generation of groundwater potential zone}

Variable factor weights (Vi) and individual factor weights (Fi) for each thematic layers have been assigned to delineate groundwater potential zone. The spatial amalgamation of all map layers has been done using the raster calculator tool of ArcGIS 10.3 software version. Finally, a linear sum combination method has been adopted for getting the groundwater potential zone in RS-GIS environment. 


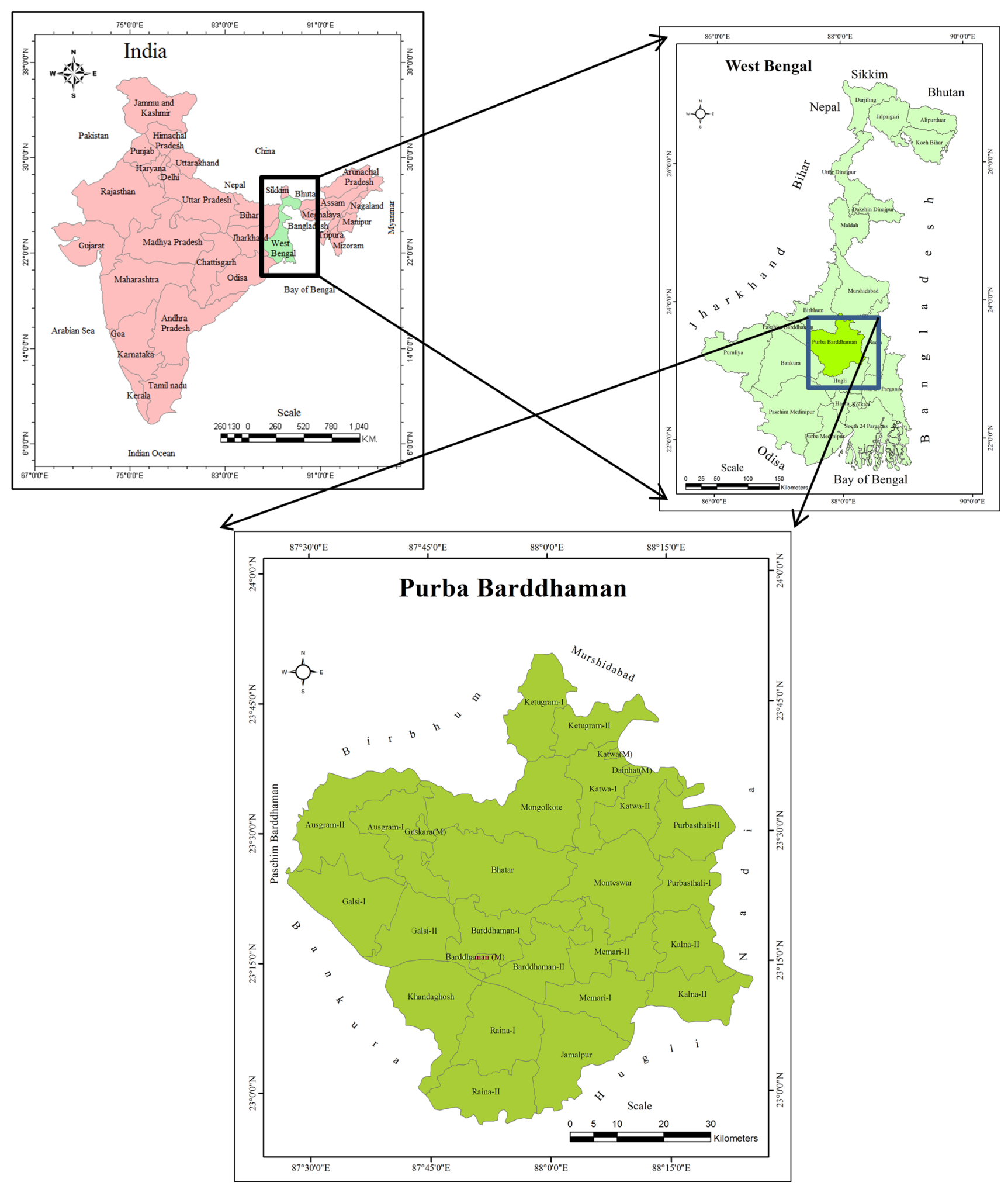

Fig. 1 Location map 
Table 1 Sources of data

\begin{tabular}{ll}
\hline Attribute & Source \\
\hline Lithological Unit & Geological Survey of India, Kolkata 2001 (Scale-1:2,50,000) \\
Soil texture & National Bureau of Soil Survey \& Land Use Planning (NBSS\&LUP), Kolkata [Soil Survey and Land \\
& Use Plan of Bardhaman District, West Bengal] \\
Rainfall & Central Ground Water Board, Government of India [Scale-1:1,000,000 \\
Land use Land cover, & LANDSAT 8, USGS \\
Surface water body & [(Path/Row: 138/44, Acquired date: 2019-01-29, Scene center time: 23:58:53Z) and (Path/Row: 139/44, \\
Groundwater data & Cequired date: 2018-12-11, Scene center time: 13:08:32Z)] \\
Groundwater depth wells data & Central Ground Water Board, Government of India \\
\hline
\end{tabular}

$\mathrm{GPZ}=\left[\left(\mathrm{Liw}^{*} \mathrm{Liwi}\right)+(\mathrm{STw} * \mathrm{STwi})+(\mathrm{DfRw} * \mathrm{DfRwi})\right.$

$$
\left.+\left(\mathrm{LULCW}^{*} \mathrm{LULCwi}\right)+(\mathrm{SWw} * \mathrm{SWwi})+(\mathrm{Rfw} * \mathrm{RFwi})\right]
$$

where $\mathrm{GPZ}=$ groundwater potential zone, $\mathrm{Li}=$ lithology, $\mathrm{ST}=$ soil texture, $\mathrm{DfR}=$ distance from river, $\mathrm{LULC}=$ land use land cover, $\mathrm{SW}=$ surface water bodies, $\mathrm{Rf}=$ rainfall, the subscripts $w$ and wi refer to the normalized weight of a theme and normalized weight of individual features of a theme, respectively.

Thereafter, the groundwater potential zone map has been validated by the CGWB bore wells data with the help of the interpolation method (Inverse distance weighted (IDW)) in the ArcGIS environment (Fig. 2).

\section{Results and discussion}

\section{Lithological unit}

Lithology acts as an important role in groundwater potential because the permeability of the rocks directly influences infiltration. The lithological unit determines the movement and prosperity of groundwater (Jhariya et al. 2016). In this study area, four types of lithological unit are found, namely laterite, clay with caliche concretion, clay alternating with silt and sand, sand-silt-clay (Fig. 3). Mainly, 53.36\% of the total area in Purba Bardhaman district clay with caliche concretion is higher than another lithological unit. Three units of lithology, i.e., Q1S, Q2K, Q2D, have been made in Pleistocene to Holocene epoch and L units in Cainozoic epoch (Table 2).

\section{Soil texture}

The soil potential depends heavily on the soil texture as the soil texture directly affects the infiltration and aquifer conditions. On the basis of porosity and permeability, the infiltration capacity of coarse-grained soil is high compared to fine-grained soil. In this study area, twelve types (Fig. 4) of soil are found which are derived from weathering of laterite soil and transportation of silt soil by the river. Soil types with their percentage of the area are shown in Table 3.

Mainly, three major types of soil in this region are sandy loam, clayey loam and silty loam. Among those types of soil, sandy loamy soil texture is more permeable than others.

\section{Distances from river}

A positive relationship has been found with river and groundwater. Rivers have multifarious interaction with groundwater. Subsurface water flow occurs from river to groundwater zone. This is an uninterrupted flow which increases the groundwater zone. When the groundwater enters the river, it is called base flow. We found a reverse relationship with the river and distance from it for the subsurface and surface flow of the river to the groundwater zone. So groundwater recharge decayed with the increase in distance from the river (Fig. 5).

\section{Land use and land cover}

Land use and land cover (LULC) is one of the vital factors which directly affect the development of groundwater recharge. Different types of land use act as differently in the runoff, infiltration and groundwater recharge. Generally, forest cover and agricultural land are most suitable for groundwater recharge. On the other hand, the built-up area is not suitable for groundwater recharge. LULC map has been prepared from mosaics of OLI-TRIS Landsat image. In this study area, LULC map has been classified into major five classes, i.e., agricultural land (36.8\%), vegetation (19.1\%), built-up area (18.97\%), fallow or others types of land $(17.89 \%)$, and water body (7.24) as shown in Fig. 6. Majority of land in this district is under the cover of agriculture and vegetation. Agricultural activities rely on monsoon rainfall, which is why most agricultural land remains vacant during the cold season. The map shows only a few urban settlements and large rural settlements (Fig. 6). In the LULC classification, water bodies, farm property, woodland, other 


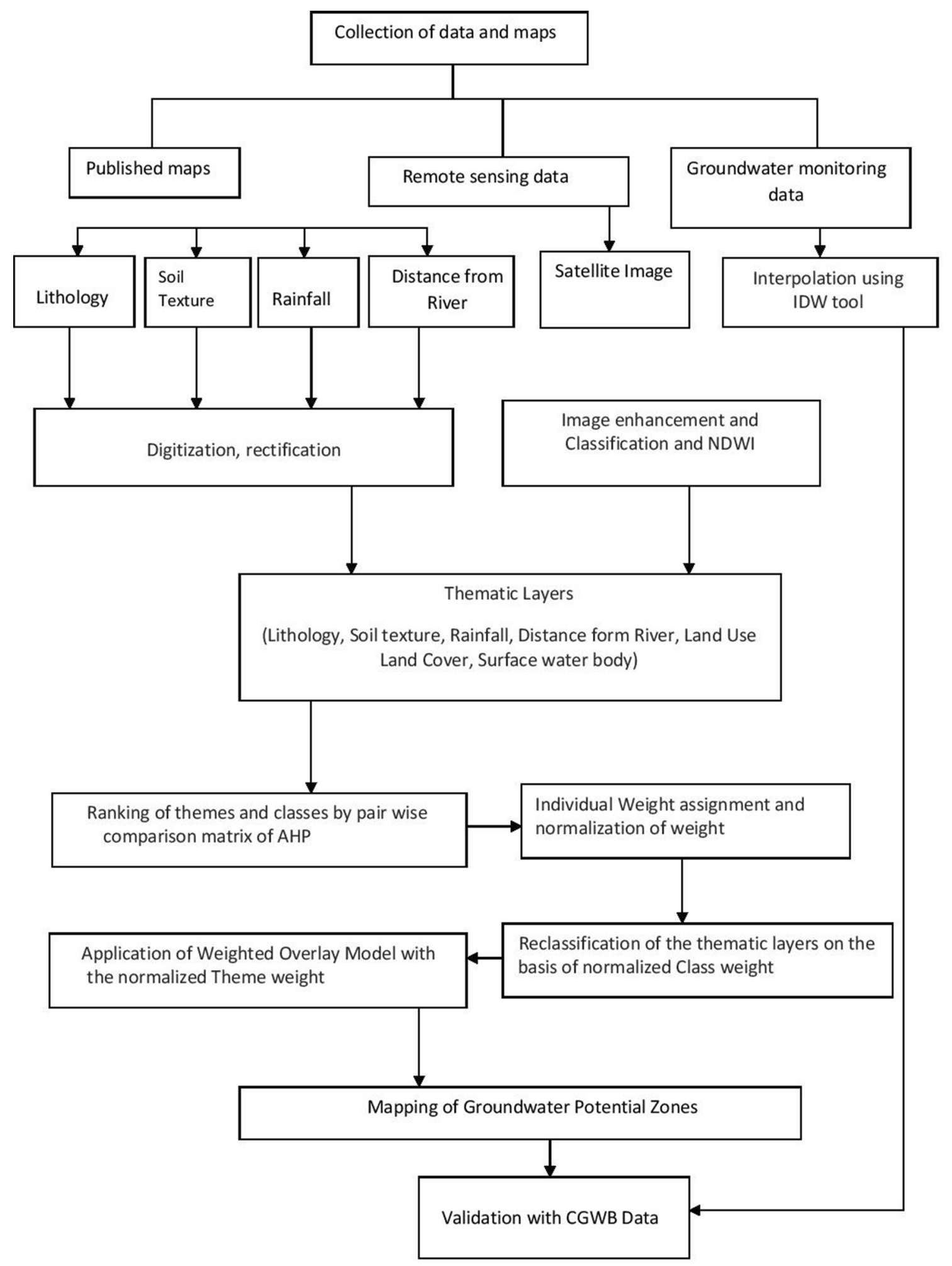

Fig. 2 Flowchart of methodology

property and built-up areas shall be given the highest to the lowest weight as shown in Table 4.

\section{Surface water body}

There is a complex interconnection between surface water and groundwater. Exchange of surface water and subsurface 


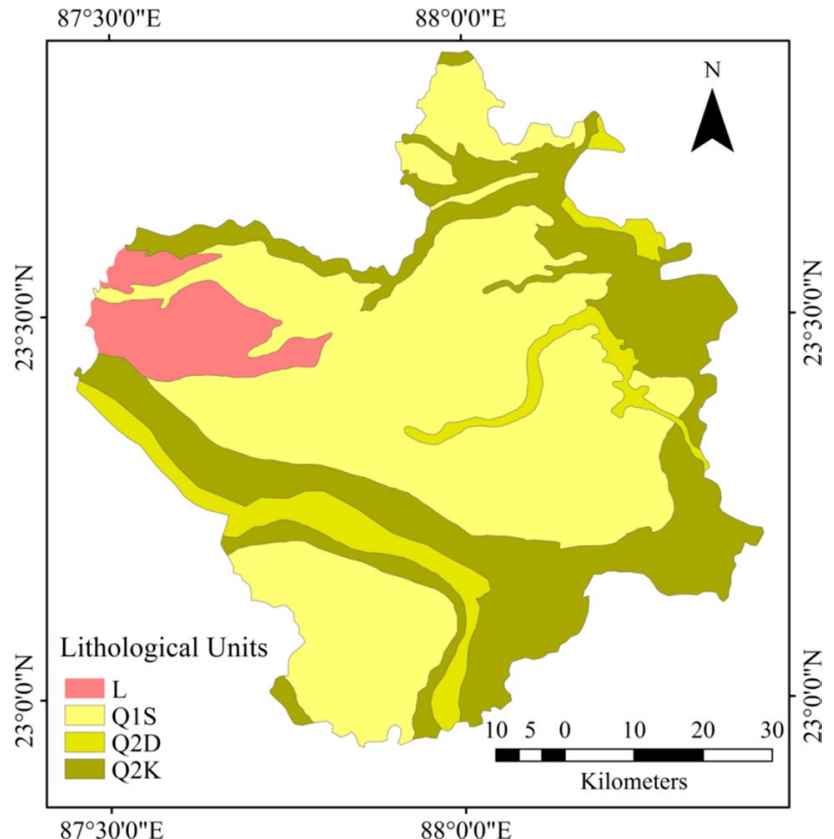

Fig. 3 Lithological map

water is a part of the hydrosphere within the land. This interaction is one of the processes of the natural hydrologic cycle. The interaction between surface water and groundwater is determined by a complex combination of geological, hydrological, geomorphological, climates and landscape factor. Surface water means water reservoirs of this earth such as lakes, swamps, ponds, wetlands, stream, etc. If the permeable rock is present below the surface water penetration stage, it plays a vital role in the recharge of groundwater. The surface water thematic map of the Landsat OLI-TRIS image using the NDWI method has been prepared in this study area as shown in Fig. 7.

\section{Rainfall}

Rainfall plays a major role in the management of subsurface and surface water sources. Several studies have been carried out using a particular method to calculate the value of rainfall in groundwater variability. The amount of rainfall in this study region is not that high. The precipitation map is divided into three parts shown in Fig. 8.

\section{Groundwater potential zone}

\section{Determination of weighting}

At first, on the basis of six major criteria, pair-wise matrix has been done with the help of the AHP method to recognize the priority and rank of the themes. Here, pair-wise matrix $m \times m$ is a real matrix, and $m$ represents the number of criteria which is considered for evaluation. In this matrix, 1-9 scale has been used. Every criterion is given preference according to Table 4 . The comparison matrix of the criterion can be set by this equation, i.e., $a_{j k} * a_{k j}=1$. The consistency ratio is calculated on the basis of the equation

$\mathrm{CR}=\mathrm{CI} / \mathrm{RI}$

where $\mathrm{CI}=$ consistency index and $\mathrm{RI}$ is the random index. Addition or elimination of a feature in the study depends upon the value of consistency ratio. The value of CR should always keep lower than or equal to 0.1 (Saaty 1990). CI

Table 2 Details of the lithological unit in geological framework

\begin{tabular}{|c|c|c|c|c|c|}
\hline \multirow[t]{2}{*}{ Lithological unit } & \multirow[t]{2}{*}{ Geological formation } & \multicolumn{2}{|l|}{ Age } & \multirow[t]{2}{*}{ Nature and Characteristics } & \multirow[t]{2}{*}{ Area in $\%$} \\
\hline & & Period & Epoch & & \\
\hline $\mathrm{L}$ & Laterite & Q & Cainozoic & Hard crust & 6.68 \\
\hline Q1S & Sijua formation & $\mathrm{U}$ & Upper Pleistocene to Middle Holocene & $\begin{array}{l}\text { Soft, unconsolidated sediments (oxi- } \\
\text { dized) }\end{array}$ & 53.36 \\
\hline Q2K & Panskura formation & $\begin{array}{l}\mathrm{T} \\
\mathrm{E} \\
\mathrm{R}\end{array}$ & Middle to Upper Holocene & $\begin{array}{l}\text { Soft, unconsolidated sediments (oxi- } \\
\text { dized) }\end{array}$ & 31.72 \\
\hline Q2D & Diara formation & $\begin{array}{l}\mathrm{N} \\
\mathrm{A} \\
\mathrm{R} \\
\mathrm{Y}\end{array}$ & Upper Holocene to Recent & $\begin{array}{l}\text { Soft, unconsolidated sediments (unoxi- } \\
\text { dized) }\end{array}$ & 8.24 \\
\hline
\end{tabular}




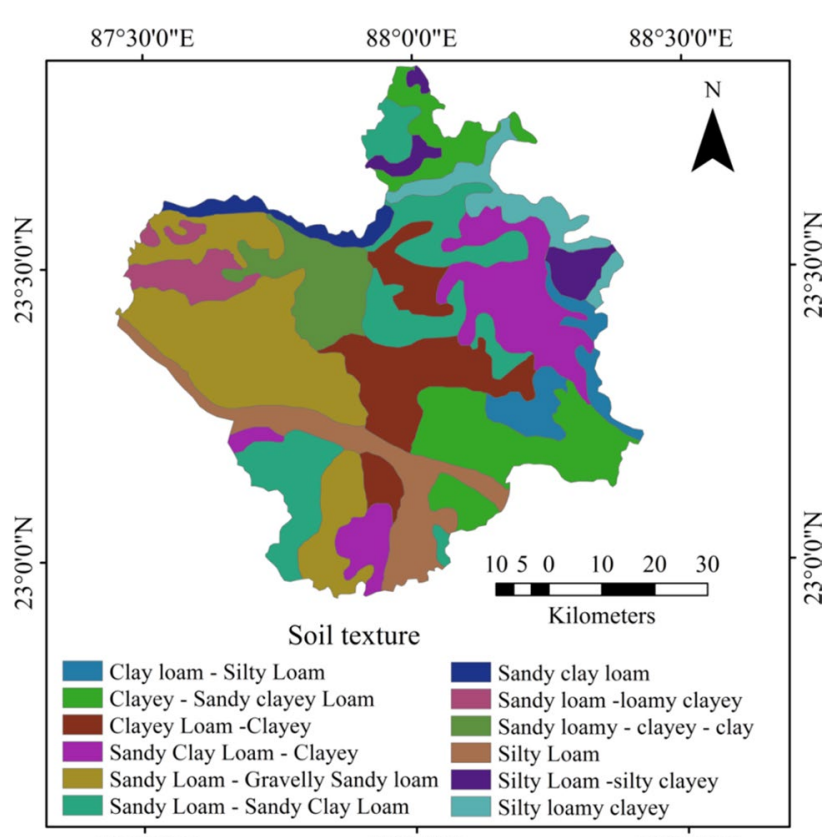

$87^{\circ} 30^{\prime} 0^{\prime \prime} \mathrm{E}$

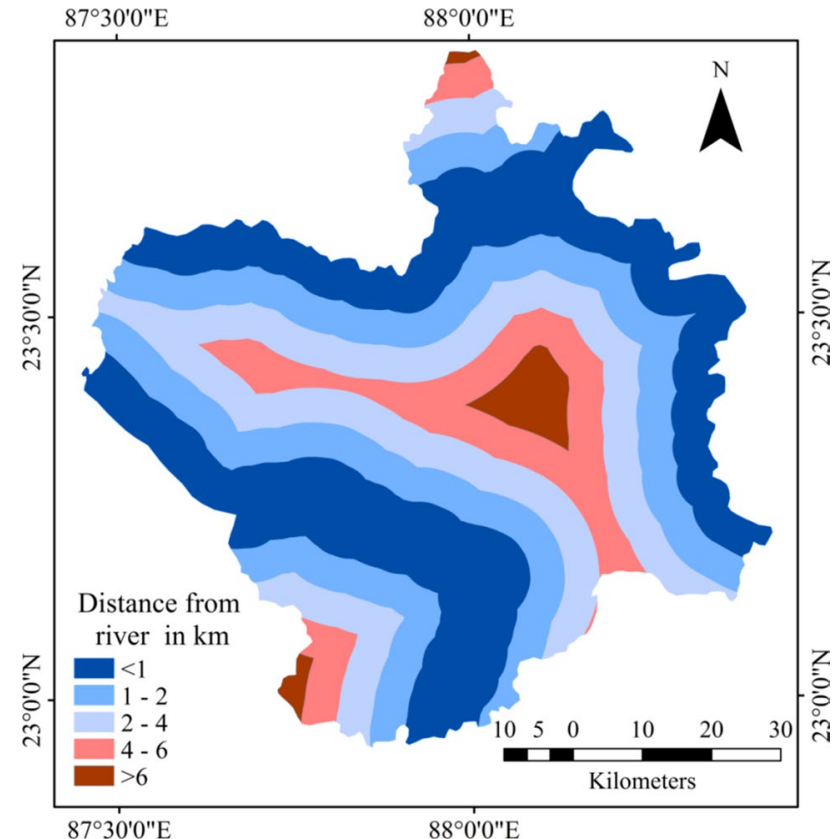

Fig. 5 Buffer zone from River

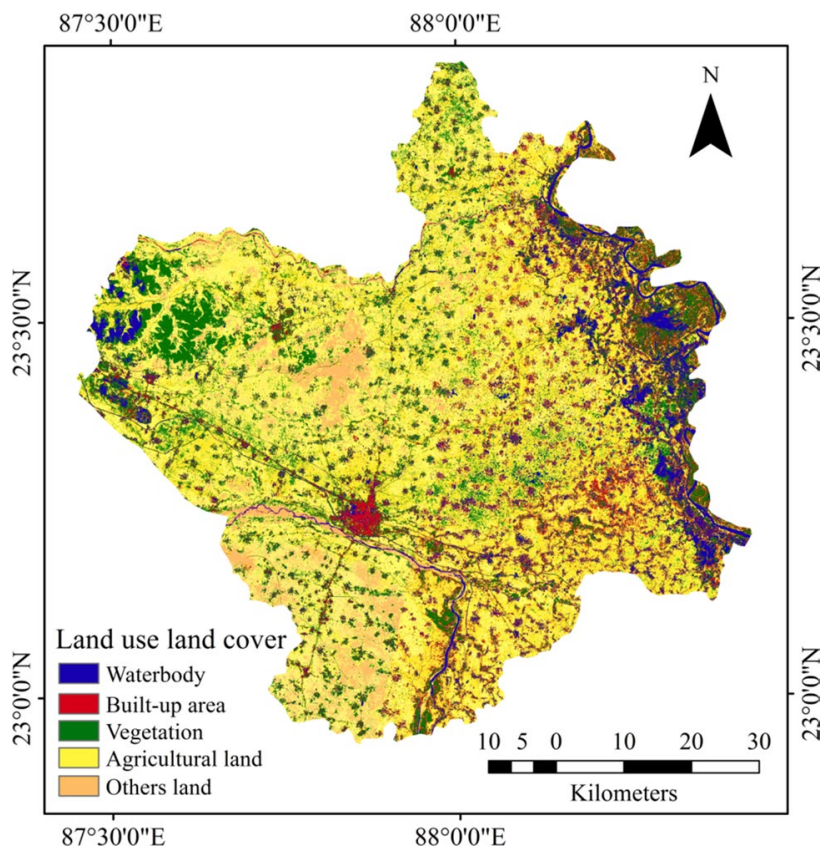

Fig. 6 Land use land cover map
Table 3 Details of soil texture with the percentage of area

\begin{tabular}{|c|c|c|c|}
\hline Serial no. & Soil texture & Description & Area in $\%$ \\
\hline 1 & $\mathrm{~S} 1$ & $\begin{array}{l}\text { Sandy loam—gravelly sandy } \\
\text { loam }\end{array}$ & 20.35 \\
\hline 2 & $\mathrm{~S} 2$ & Sandy loam-loamy clayey & 3.17 \\
\hline 3 & $\mathrm{~S} 3$ & Sandy loam—sandy clay loam & 13.86 \\
\hline 4 & $\mathrm{~S} 4$ & Sandy clay loam-clayey & 10.83 \\
\hline 5 & S5 & Clayey loam-clayey & 10.79 \\
\hline 6 & S6 & $\begin{array}{l}\text { Sandy loamy-clayey-clay } \\
\text { Loam }\end{array}$ & 5.72 \\
\hline 7 & S7 & Clay loam—silty loam & 5.61 \\
\hline 8 & S8 & Clayey_sandy clayey loam & 13.01 \\
\hline 9 & S9 & Silty loam—silty clayey & 2.6 \\
\hline 10 & $\mathrm{~S} 10$ & Silty loamy clayey & 4.12 \\
\hline 11 & S11 & Silty loam & 7.96 \\
\hline 12 & $\mathrm{~S} 12$ & Sandy clay loam & 1.98 \\
\hline
\end{tabular}

Fig. 4 Soil texture map

\section{în}

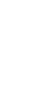


Table 4 Pair-wise comparison matrix for AHP and priority and rank of themes

\begin{tabular}{|c|c|c|c|c|c|c|c|c|c|c|}
\hline \multirow[t]{2}{*}{ Serial no. } & \multirow[t]{2}{*}{ Category } & \multicolumn{6}{|c|}{ AHP weightage values } & \multirow[t]{2}{*}{ Priority $(\%)$} & \multirow[t]{2}{*}{ Rank } & \multirow[t]{2}{*}{ AHP Weight } \\
\hline & & 1 & 2 & 3 & 4 & 5 & 6 & & & \\
\hline 1 & Lithological unit & 1 & 1.00 & 2.00 & 2.00 & 3.00 & 4.00 & 27.1 & 1 & 0.271 \\
\hline 2 & Soil texture & 1.00 & 1 & 2.00 & 2.00 & 3.00 & 3.00 & 26.2 & 2 & 0.262 \\
\hline 3 & Distance from river & 0.50 & 0.50 & 1 & 2.00 & 3.00 & 3.00 & 18.8 & 3 & 0.188 \\
\hline 4 & Land use land cover & 0.50 & 0.50 & 0.50 & 1 & 2.00 & 3.00 & 13.7 & 4 & 0.137 \\
\hline 5 & Surface water body & 0.33 & 0.33 & 0.33 & 0.50 & 1 & 2.00 & 8.3 & 5 & 0.083 \\
\hline 6 & Rainfall & 0.25 & 0.33 & 0.33 & 0.33 & 0.50 & 1 & 5.9 & 6 & 0.059 \\
\hline $\mathrm{CR}=2.3 \%$ & & & & & & & & & & \\
\hline
\end{tabular}

$87^{\circ} 30^{\prime} 0^{\prime \prime} \mathrm{E}$

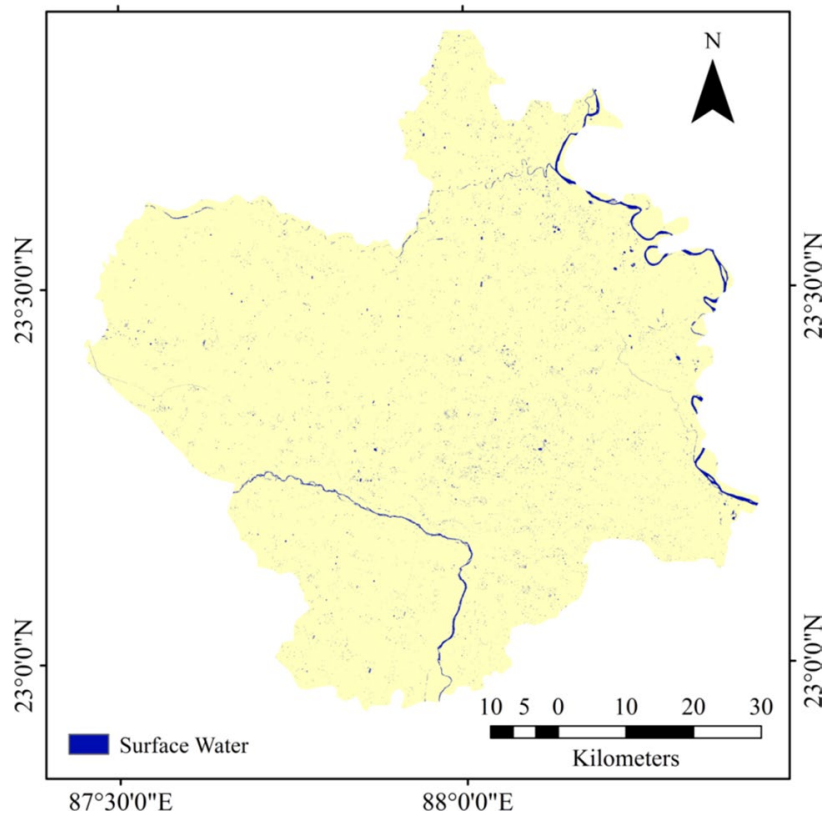

Fig. 7 Surface water map

reflects the consistency of one's judgment. CI can be calculated by the following equation

$\mathrm{CI}=\lambda \max -n / n$

where $n=$ order of the matrix, $\lambda \max$ is the largest eigenvalue. $\mathrm{CR}$ of each and every individual feature is observed for the inclusion or exclusion in the study.

Calculated priority, rank and AHP weight of individual are presented in Table 4 with the help of above-mentioned procedure and consistency ratio is $2.3 \%$ which is below $10 \%$ and accepted according to Saaty (1994). The weightage of each class of every parameter has been calculated and presented in Table 5.

The groundwater potential zone map is classified in five distinct zones representing very low potential, low potential,

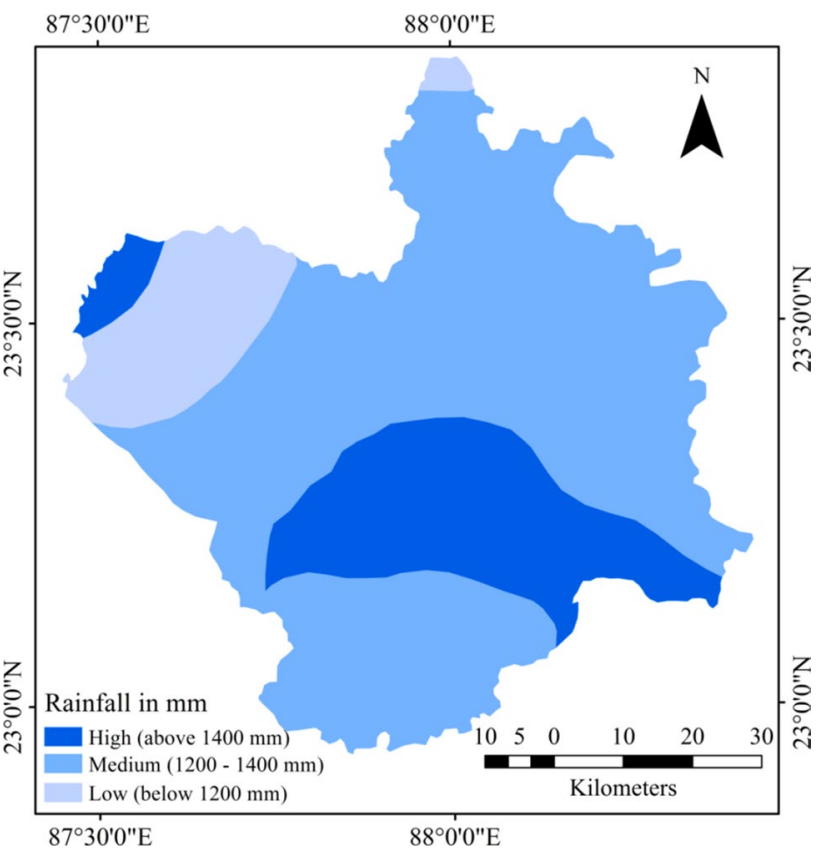

Fig. 8 Rainfall distribution map

medium potential, high potential and very high potential which consist of area of $21.54 \%, 35.8 \%, 26.47 \%, 10.13 \%$ and $6.06 \%$ of total area. In this district, very high potential and high potential zone areas are found in the side of river Damodar, Ganga and Ajay and dense vegetation areas of the west part of this district, shown in Fig. 9.

\section{Validation}

The groundwater potential zone area was verified with the help of 12 dug well station and 32 tube well data of 44 stations that were collected from CGWB-2018. These 44 stations are distributed throughout the district shown in Fig. 10. Details of tube well location and actual yield are shown in Table 6. 
Table 5 Weightage of different parameters for groundwater potential zones mapping

\begin{tabular}{|c|c|c|c|c|c|c|c|c|c|c|c|c|c|c|}
\hline \multirow[t]{2}{*}{ Factor } & \multirow[t]{2}{*}{ Sub-class } & \multicolumn{12}{|c|}{ AHP weightage values } & \multirow[t]{2}{*}{ AHP weight } \\
\hline & & 1 & 2 & 3 & 4 & 5 & 6 & 7 & 8 & 9 & 10 & 11 & 12 & \\
\hline \multirow[t]{4}{*}{ Lithological unit } & Q1S & 1 & 2.00 & 3.00 & 5.00 & & & & & & & & & 0.483 \\
\hline & Q2D & 0.50 & 1 & 2.00 & 3.00 & & & & & & & & & 0.272 \\
\hline & Q2K & 0.33 & 0.50 & 1 & 2.00 & & & & & & & & & 0.157 \\
\hline & $\mathrm{L}$ & 0.20 & 0.33 & 0.50 & 1 & & & & & & & & & 0.088 \\
\hline \multicolumn{15}{|l|}{$\mathrm{CR}=0.005$} \\
\hline \multirow[t]{12}{*}{ Soil texture } & $\mathrm{S} 1$ & 1 & 3.00 & 3.00 & 3.00 & 3.00 & 3.00 & 4.00 & 4.00 & 4.00 & 5.00 & 5.00 & 5.00 & 0.229 \\
\hline & $\mathrm{S} 2$ & 0.33 & 1 & 1.00 & 1.00 & 1.00 & 1.00 & 3.00 & 3.00 & 3.00 & 4.00 & 4.00 & 4.00 & 0.011 \\
\hline & $\mathrm{S} 3$ & 0.33 & 1.00 & 1 & 1.00 & 1.00 & 1.00 & 3.00 & 3.00 & 3.00 & 4.00 & 4.00 & 4.00 & 0.011 \\
\hline & $\mathrm{S} 4$ & 0.33 & 1.00 & 1.00 & 1 & 1.00 & 1.00 & 3.00 & 3.00 & 3.00 & 4.00 & 4.00 & 4.00 & 0.011 \\
\hline & S5 & 0.33 & 1.00 & 1.00 & 1.00 & 1 & 1.00 & 3.00 & 3.00 & 3.00 & 4.00 & 4.00 & 4.00 & 0.011 \\
\hline & S6 & 0.33 & 1.00 & 1.00 & 1.00 & 1.00 & 1 & 3.00 & 3.00 & 3.00 & 4.00 & 4.00 & 4.00 & 0.011 \\
\hline & S7 & 0.25 & 0.33 & 0.33 & 0.33 & 0.33 & 0.33 & 1 & 1.00 & 1.00 & 3.00 & 3.00 & 3.00 & 0.049 \\
\hline & S8 & 0.25 & 0.33 & 0.33 & 0.33 & 0.33 & 0.33 & 1.00 & 1 & 1.00 & 3.00 & 3.00 & 3.00 & 0.049 \\
\hline & S9 & 0.25 & 0.33 & 0.33 & 0.33 & 0.33 & 0.33 & 1.00 & 1.00 & 1 & 3.00 & 3.00 & 3.00 & 0.049 \\
\hline & $\mathrm{S} 10$ & 0.20 & 0.25 & 0.25 & 0.25 & 0.25 & 0.25 & 0.33 & 0.33 & 0.33 & 1 & 1.00 & 1.00 & 0.025 \\
\hline & $\mathrm{S} 11$ & 0.20 & 0.25 & 0.25 & 0.25 & 0.25 & 0.25 & 0.33 & 0.33 & 0.33 & 1.00 & 1 & 1.00 & 0.025 \\
\hline & $\mathrm{S} 12$ & 0.20 & 0.25 & 0.25 & 0.25 & 0.25 & 0.25 & 0.33 & 0.33 & 0.33 & 1.00 & 1.00 & 1 & 0.025 \\
\hline \multicolumn{15}{|l|}{$\mathrm{CR}=0.024$} \\
\hline \multirow[t]{5}{*}{ Distance from river (in $\mathrm{km}$ ) } & $<1$ & 1 & 2.00 & 3.00 & 4.00 & 5.00 & & & & & & & & 0.419 \\
\hline & $1-2$ & 0.50 & 1 & 2.00 & 3.00 & 4.00 & & & & & & & & 0.263 \\
\hline & $2-4$ & 0.33 & 0.50 & 1 & 2.00 & 3.00 & & & & & & & & 0.160 \\
\hline & $4-6$ & 0.25 & 0.33 & 0.50 & 1 & 2.00 & & & & & & & & 0.097 \\
\hline & $>6$ & 0.20 & 0.25 & 0.33 & 0.50 & 1 & & & & & & & & 0.062 \\
\hline \multicolumn{15}{|l|}{$\mathrm{CR}=0.015$} \\
\hline \multirow[t]{5}{*}{ Land use land cover } & Water & 1 & 2.00 & 3.00 & 4.00 & 5.00 & & & & & & & & 0.419 \\
\hline & Agricultural land & 0.50 & 1 & 2.00 & 3.00 & 4.00 & & & & & & & & 0.263 \\
\hline & Vegetation & 0.33 & 0.50 & 1 & 2.00 & 3.00 & & & & & & & & 0.160 \\
\hline & Others land & 0.25 & 0.33 & 0.50 & 1 & 2.00 & & & & & & & & 0.097 \\
\hline & Built up area & 0.20 & 0.25 & 0.33 & 0.50 & 1 & & & & & & & & 0.062 \\
\hline \multicolumn{15}{|l|}{$\mathrm{CR}=0.015$} \\
\hline \multirow[t]{2}{*}{ Surface water body } & Water body & 1 & 5.00 & & & & & & & & & & & 0.833 \\
\hline & Others & 0.20 & 1 & & & & & & & & & & & 0.167 \\
\hline \multicolumn{15}{|l|}{$\mathrm{CR}=0.0$} \\
\hline \multirow[t]{3}{*}{ Rainfall } & High & 1 & 2.00 & 3.00 & & & & & & & & & & 0.540 \\
\hline & Medium & 0.50 & 1 & 2.00 & & & & & & & & & & 0.297 \\
\hline & Low & 0.33 & 0.50 & 1 & & & & & & & & & & 0.163 \\
\hline $\mathrm{CR}=0.01$ & & & & & & & & & & & & & & \\
\hline
\end{tabular}

Table 6 expresses similarity between actual class and expected class. A remark of agreement and disagreement is also prepared in Table 6 . In this study area, the total number of tube well and dug well is 44 . The number of tube well and dug well under the agreement of coherence between actual and predicted yield range is 39 , and the number of tube well and dug well under disagreement of coherence between actual and predicted yield range is 5 .
The equation of accuracy prediction

$=$ No. of tube well and dug well under the agreement of coherence

/Total number of tube well and dug well surveyed $\times 100$

$=39 / 44 \times 100$

$=88.64 \%$ 


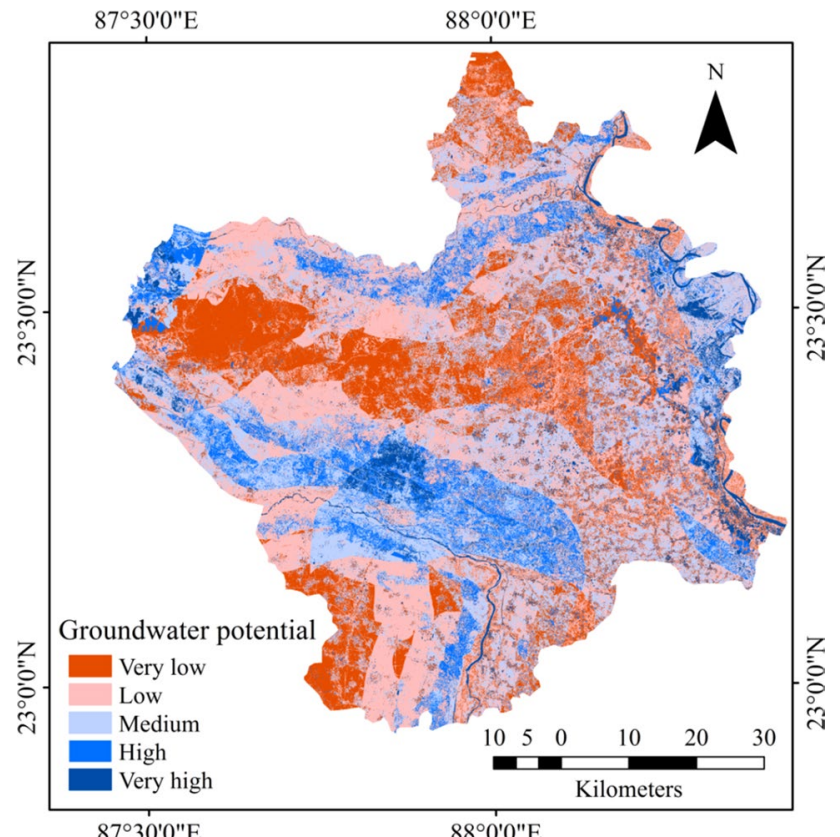

Fig. 9 Groundwater potential zone map

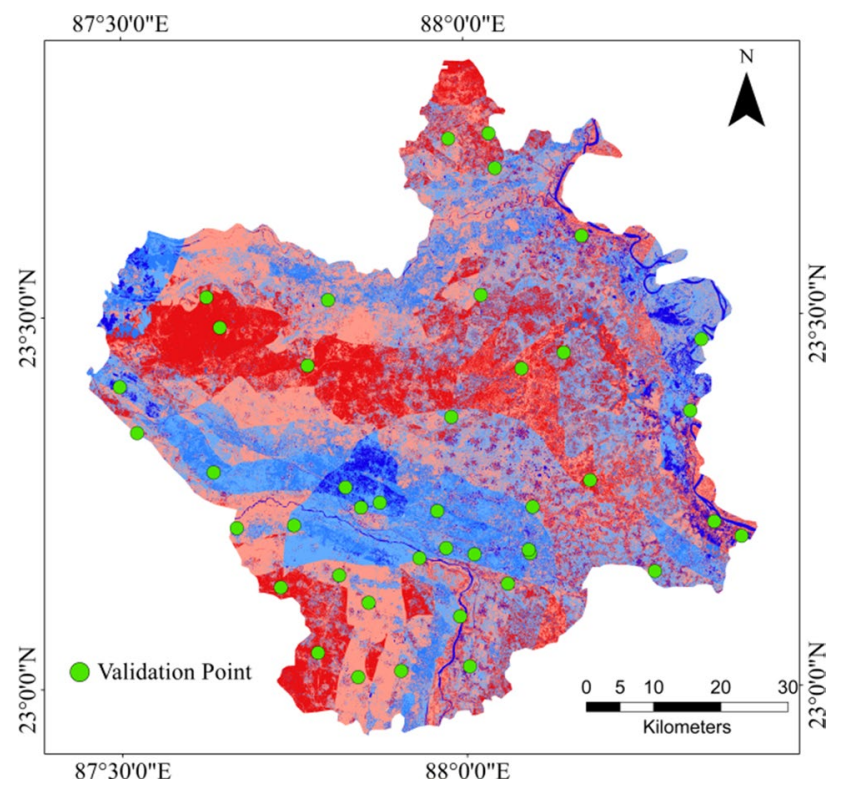

Fig. 10 Groundwater validation point
The prediction accuracy value of 88.64 reflects the fact that the AHP model and GIS techniques used in this work are significantly robust and accurate. For validation of this work, groundwater depth zone map (Fig. 11) prepared using the IDW method in ArcGIS is applied and it is compared with the potential zone map (Fig. 10). In order to demonstrate the accuracy, the receiver operating characteristic (ROC) curve was used in this analysis, which compares the tube well data with the groundwater potential area. The ROC curve represents (Fig. 12) that the area under curve (AUC) is 0.868 which means $86.8 \%$. So this ROC result also accepts the AHP model in this work.

\section{Conclusion}

Groundwater is the world's greatest resource. Groundwater contamination is a big problem for our future climate. To this end, the purpose of this paper is to explore potential groundwater zones using AHP and GIS techniques in the Purba Bardhaman district. In this analysis, six main parameters were taken into account to determine the potential groundwater zone. Low and very low potential zones account for $57.34 \%$ of the total area, although the Purba Bardhaman district is a deltaic region. The rest of $43.38 \%$ area was covered with medium to very high groundwater potentiality zones. It is obvious that the porous lithological setting, permeable soil texture, location of surface water bodied coupled with rainfall distribution and vegetative cover result in the formation of a high potential area. The central part of the district is mainly characterized by a low and very low field. These areas have low strength, irrespective of the distance from the sea. This work is much more important in the age of drinking water crisis, as this final map would have been useful in the planning and management of water resources. This work has been validated with the results of the 44 tube well station. The empirical study IDW method is used to test and show the precision of the receiver operating characteristic (ROC) curve. The method used is reliable and can be used successfully elsewhere with the required modifications. This study would enable the decision-makers concerned to establish an appropriate study policy. 
Table 6 Detail account of the validation points

\begin{tabular}{|c|c|c|c|c|c|c|c|c|c|}
\hline Serial no. & Block name & Latitude & Longitude & Site name & Site type & Well code & Actual class & Estimated class & $\begin{array}{l}\text { Similarity between } \\
\text { actual class and } \\
\text { expected class }\end{array}$ \\
\hline 1 & Ausgram-i & 23.52722 & 87.6238889 & Bannabagram-1 & Tube Well & W10222 & High & Low & No \\
\hline 2 & Bardhaman & 23.24361 & 87.8475 & Amra & Dug Well & W20989 & Very high & Very high & Yes \\
\hline 3 & Bardhaman & 23.25 & 87.875 & Bardhaman & Dug Well & W10230 & Very high & Very high & Yes \\
\hline 4 & Bardhaman & 23.23833 & 87.9583333 & Raipur2 & Dug Well & W28308 & Very high & Very high & Yes \\
\hline 5 & Bardhaman & 23.27083 & 87.825 & Jhinguti & Tube Well & W10231 & Medium & Medium & Yes \\
\hline 6 & Bhatar & 23.36472 & 87.9797222 & Kubajpur & Dug Well & W28409 & Very low & Very low & Yes \\
\hline 7 & Bhatar & 23.43472 & 87.7708333 & Orgram & Dug Well & W10235 & Very low & Very low & Yes \\
\hline 8 & Bhatar & 23.43472 & 87.7708333 & Orgram Pz-2 & Tube Well & W28470 & Very low & Very low & Yes \\
\hline 9 & Galsi-i & 23.345 & 87.5222222 & Kasba & Tube Well & W10250 & Very high & High & No \\
\hline 10 & Galsi-i & 23.40694 & 87.4972222 & Bud Bud Pz-1 & Tube Well & W10247 & Very high & Very high & Yes \\
\hline 11 & Galsi-i & 23.48639 & 87.6433333 & $\begin{array}{l}\text { Chak-Radhamo- } \\
\text { hanpur }\end{array}$ & Dug Well & W28503 & Very high & Low & No \\
\hline 12 & Galsi-ii & 23.29167 & 87.6333333 & Galsi & Tube Well & W10253 & High & High & Yes \\
\hline 13 & Jamalpur & 23.14 & 88.0602778 & Ajhapur1 & Dug Well & W28212 & Very high & Very high & Yes \\
\hline 14 & Jamalpur & 23.02917 & 88.0041667 & Chakdigi & Tube Well & W10261 & High & High & Yes \\
\hline 15 & Jamalpur & 23.09639 & 87.9905556 & $\begin{array}{l}\text { Berugram (Mor- } \\
\text { alpara) }\end{array}$ & Dug Well & W28185 & Very high & Very high & Yes \\
\hline 16 & Kalna-i & 23.27833 & 88.1808333 & $\begin{array}{l}\text { Madhyamgram } \\
\text { Pz }\end{array}$ & Tube Well & W10270 & Medium & Medium & Yes \\
\hline 17 & Kalna-ii & 23.15528 & 88.2738889 & Bara Dhamas & Tube Well & W10272 & Low & Medium & No \\
\hline 18 & Kalna-ii & 23.22139 & 88.3608333 & Kalna & Tube Well & W10274 & High & High & Yes \\
\hline 19 & Kalna-ii & 23.20167 & 88.4002778 & Bandebaz & Dug Well & W28278 & Very high & Very high & Yes \\
\hline 20 & Kalna-ii & 23.15528 & 88.2738889 & Bara Dhamas & Tube Well & W10272 & Low & Low & Yes \\
\hline 21 & Katwa-i & 23.60694 & 88.1711111 & Dainhat2 & Dug Well & W28570 & Very high & Very high & Yes \\
\hline 22 & Ketugram-i & 23.73889 & 87.9777778 & Ramjibanpur & Tube Well & W11151 & Low & Low & Yes \\
\hline 23 & Ketugram-i & 23.74556 & 88.0366667 & Hat Murgram & Tube Well & W10288 & Low & Low & Yes \\
\hline 24 & Ketugram-ii & 23.69889 & 88.0455556 & Ketugram1 & Tube Well & W28631 & Low & Low & Yes \\
\hline 25 & Kandaghosh & 23.22 & 87.75 & Khejurhati1 & Dug Well & W28299 & High & High & Yes \\
\hline 26 & Kandaghosh & 23.13667 & 87.7302778 & Bowaichandi & Tube Well & W28210 & Medium & Medium & Yes \\
\hline 27 & Kandaghosh & 23.21667 & 87.6666667 & Metedanga-2 & Tube Well & W10278 & High & High & Yes \\
\hline 28 & Memari-i & 23.18833 & 87.9708333 & Barsul Pz & Tube Well & W10306 & Very high & Very high & Yes \\
\hline 29 & Memari-i & 23.18083 & 88.0927778 & Memari1 & Bore Well & W28255 & Very high & Very high & yes \\
\hline 30 & Memari-i & 23.17972 & 88.0119444 & Pallaroad Pz & Tube Well & W28252 & High & High & Yes \\
\hline 31 & Memari-i & 23.18528 & 88.0908333 & $\begin{array}{l}\text { Dakshin Radha- } \\
\text { kantapur }\end{array}$ & Dug Well & W28259 & High & Very high & No \\
\hline 32 & Memari-ii & 23.24306 & 88.0969444 & Paharhati & Tube Well & W10312 & Low & Low & Yes \\
\hline 33 & Mangalkot & 23.52833 & 88.0238889 & Koichor & Tube Well & W10298 & Very low & Very low & Yes \\
\hline 34 & Mangalkot & 23.52278 & 87.8011111 & Charnak Pz & Tube Well & W10297 & Low & Low & Yes \\
\hline 35 & Manteswar & 23.42917 & 88.0822222 & Maldanga & Tube Well & W28468 & Very low & Very low & Yes \\
\hline 36 & Manteswar & 23.45028 & 88.1438889 & Denur & Bore Well & W28480 & Very low & Very low & Yes \\
\hline 37 & Purbasthali-i & 23.37083 & 88.3275 & Samuagrah & Tube Well & W28413 & High & High & Yes \\
\hline 38 & Purbasthali-ii & 23.46667 & 88.3444444 & Chupi & Tube Well & W28490 & High & High & Yes \\
\hline 39 & Rayna-i & 23.11556 & 87.8577778 & Rayna Pz & Tube Well & W28199 & Low & Low & Yes \\
\hline 40 & Rayna-i & 23.1525 & 87.8152778 & Sagrai Pz (swid) & Tube Well & W28219 & low & low & yes \\
\hline 41 & Rayna-i & 23.175 & 87.9319444 & Haripur3 & Tube Well & W28249 & High & High & Yes \\
\hline 42 & Rayna-ii & 23.01556 & 87.8419444 & Kaity & Tube Well & W10325 & Medium & Medium & Yes \\
\hline 43 & Rayna-ii & 23.02361 & 87.9044444 & $\begin{array}{l}\text { Barpur } \\
\quad \text { (pashanda) }\end{array}$ & Tube Well & W28134 & High & High & Yes \\
\hline 44 & Rayna-ii & 23.04861 & 87.7838889 & Dommara $\mathrm{Pz}$ & Tube Well & W10324 & Medium & Very low & No \\
\hline
\end{tabular}




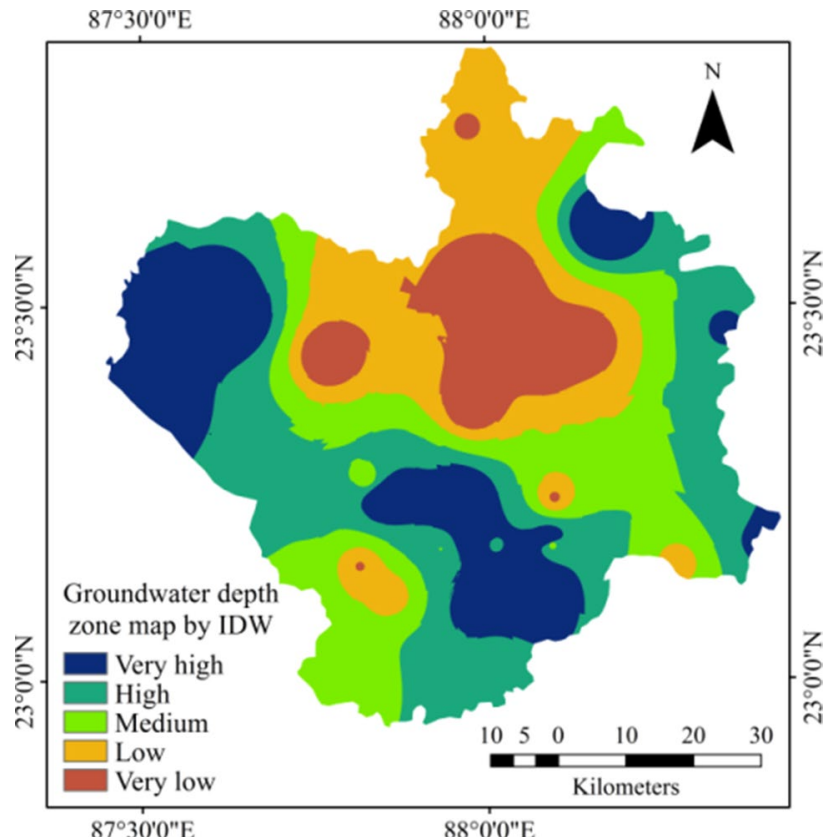

Fig. 11 Ground water depth zone

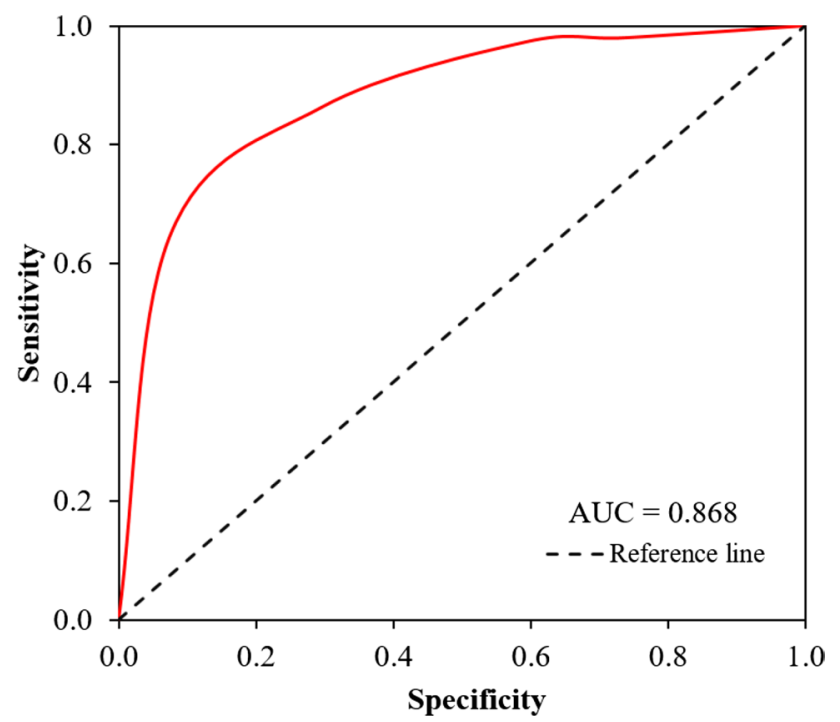

Fig. 12 Receiver operating characteristic (ROC) curve

\section{Compliance with ethical standards}

Conflict of interest There is no conflict of interest among the authors.

Open Access This article is licensed under a Creative Commons Attribution 4.0 International License, which permits use, sharing, adaptation, distribution and reproduction in any medium or format, as long as you give appropriate credit to the original author(s) and the source, provide a link to the Creative Commons licence, and indicate if changes were made. The images or other third party material in this article are included in the article's Creative Commons licence, unless indicated otherwise in a credit line to the material. If material is not included in the article's Creative Commons licence and your intended use is not permitted by statutory regulation or exceeds the permitted use, you will need to obtain permission directly from the copyright holder. To view a copy of this licence, visit http://creativecommons.org/licenses/by/4.0/.

\section{References}

Anbazhagan S, Jothibasu A (2016) Geoinformatics in groundwater potential mapping and sustainable development: a case study from southern India. Hydrol Sci J 61(6):1109-1123

Central Ground Water Board (2013) Dynamic ground water resources of India. Ministry of Water Resources, River Development and Ganga Rejuvenation, Government of India

Central Ground Water Board of India (CGWB) (2016) Report of the ground water resource estimation committee, Ministry of Water Resources, Govt. of India. http://cgwb.gov.in/Documents/GEC20 16_Report_Final\%2030.10.2017.pdf

Chakrabortty R, Pal SC, Malik S, Das B (2018) Modeling and mapping of groundwater potentiality zones using AHP and GIS technique: a case study of Raniganj Block, Paschim Bardhaman, West Bengal. Model Earth Syst Environ 4(3):1085-1110

Chen Y, Li KW, Liu SF (2011) An OWA-TOPSIS method for multiple criteria decision analysis. Expert Syst Appl 38(5):5205-5211

Choudhari PP, Nigam GK, Singh SK, Thakur S (2018) Morphometric based prioritization of watershed for groundwater potential of Mula river basin, Maharashtra, India. Geol Ecol Landsc 2(4):256-267

Cisneros JM, Grau JB, Antón JM, De Prada JD, Cantero A, Degioanni AJ (2011) Assessing multi-criteria approaches with environmental, economic and social attributes, weights and procedures: a case study in the Pampas, Argentina. Agric Water Manag 98(10):1545-1556

Das S (2017) Delineation of groundwater potential zone in hard rock terrain in Gangajalghati block, Bankura district, India using remote sensing and GIS techniques. Model Earth Syst Environ 3(4):1589-1599

Das B, Pal SC (2019a) Assessment of groundwater recharge and its potential zone identification in groundwater-stressed GoghatI block of Hugli District, West Bengal, India. Environ Dev Sustain:1-19

Das B, Pal SC (2019b) Combination of GIS and fuzzy-AHP for delineating groundwater recharge potential zones in the critical GoghatII block of West Bengal, India. HydroResearch 2:21-30

Das B, Pal SC (2020) Assessment of groundwater vulnerability to overexploitation using MCDA, AHP, fuzzy logic and novel ensemble models: a case study of Goghat-I and II blocks of West Bengal, India. Environ Earth Sci 79(5):1-16

Das S, Gupta A, Ghosh S (2017) Exploring groundwater potential zones using MIF technique in semi-arid region: a case study of Hingoli district, Maharashtra. Spat Inf Res 25(6):749-756

Das B, Pal SC, Malik S, Chakrabortty R (2019) Modeling groundwater potential zones of Puruliya district, West Bengal, India using remote sensing and GIS techniques. Geol Ecol Landsc 3(3):223-237

Dasho OA, Ariyibi EA, Akinluyi FO, Awoyemi MO, Adebayo AS (2017) Application of satellite remote sensing to groundwater potential modeling in Ejigbo area, Southwestern Nigeria. Model Earth Syst Environ 3(2):615-633 
Jhariya DC, Kumar T, Gobinath M, Diwan P, Kishore N (2016) Assessment of groundwater potential zone using remote sensing, GIS and multi criteria decision analysis techniques. J Geol Soc India 88(4):481-492

Jothibasu A, Anbazhagan S (2016) Modeling groundwater probability index in Ponnaiyar River basin of South India using analytic hierarchy process. Model Earth Syst Environ 2(3):109

Jothibasu A, Anbazhagan S (2017) Spatial mapping of groundwater potential in Ponnaiyar River basin using probabilistic-based frequency ratio model. Model Earth Syst Environ 3(1):33

Krishnamurthy J, Venkatesa Kumar N, Jayaraman V, Manivel M (1996) An approach to demarcate ground water potential zones through remote sensing and a geographical information system. Int $\mathbf{J}$ Remote Sens 17(10):1867-1884

Machiwal D, Rangi N, Sharma A (2015) Integrated knowledge-and data-driven approaches for groundwater potential zoning using GIS and multi-criteria decision making techniques on hard-rock terrain of Ahar catchment, Rajasthan, India. Environ Earth Sci 73(4):1871-1892

Ozturk D, Batuk F (2011) Implementation of GIS-based multicriteria decision analysis with VB in ArcGIS. Int J Inf Technol Decis Making 10(06): 1023-1042

Pal SC, Das B, Malik S (2019) Potential landslide vulnerability zonation using integrated analytic hierarchy process and gis technique of upper rangit catchment Area, West Sikkim, India. J Indian Soc Remote Sens 47(10):1643-1655

Pothiraj P, Rajagopalan B (2013) A GIS and remote sensing based evaluation of groundwater potential zones in a hard rock terrain of Vaigai sub-basin, India. Arab J Geosci 6(7):2391-2407
Rodell M, Velicogna I, Famiglietti JS (2009) Satellite-based estimates of groundwater depletion in India. Nature 460(7258):999

Saaty TL (1977) A scaling method for priorities in hierarchical structures. J Math Psychol 15(3):234-281

Saaty TL (1990) Decision making for leaders: the analytic hierarchy process for decisions in a complex world. RWS publications

Saaty TL (1994) How to make a decision: the analytic hierarchy process. Interfaces 24(6):19-43

Saaty TL (1999) Basic theory of the analytic hierarchy process: How to make a decision. Revista De La Real Academia De Ciencias Exactas Físicas Y Naturales 93(4):395-423

Saaty TL (2000) Fundamentals of decision making and priority theory with the analytic hierarchy process (vol 6). RWS publications

Saaty TL, Vargas LG (2001) The decision by the US congress on China's trade status: a multicriteria analysis. In: Models, methods, concepts \& applications of the analytic hierarchy process. Springer, Boston, MA, pp 305-317

Sar N, Khan A, Chatterjee S, Das A (2015) Hydrologic delineation of ground water potential zones using geospatial technique for Keleghai river basin, India. Model Earth Syst Environ 1(3):25

Zeng J, An M, Smith NJ (2007) Application of a fuzzy based decision making methodology to construction project risk assessment. Int J Project Manag 25(6):589-600

Publisher's Note Springer Nature remains neutral with regard to jurisdictional claims in published maps and institutional affiliations. 